May, 2009

MARKET RISK PREMIUM USED BY PROFESSORS IN 2008:

A SURVEY WITH 1,400 ANSWERS

\author{
Pablo Fernández
}




\title{
MARKET RISK PREMIUM USED BY PROFESSORS IN 2008: A SURVEY WITH 1,400 ANSWERS
}

\author{
Pablo Fernández ${ }^{1}$
}

\section{Abstract}

The average Market Risk Premium (MRP) used in 2008 by professors in the United States (6.3\%) was higher than the one used by their colleagues in Europe (5.3\%). We also report statistics for 18 countries: the average MRP used in 2008 ranges from 4.1\% (Belgium) to 10.5\% (India).

The dispersion of the MRP used was high: the average MRP used by professors of the same institution range was $3.5 \%$ and that of the same country was $6.9 \%$.

The average MRP used in 2007 was 1.5\% lower than the one used in 2000. 15\% of the professors decreased their MRP in 2008 (1.5\% on average) and 24\% increased it (2\% on average). $66 \%$ of the professors used a lower MRP in 2007 than in 2000 (22\% used a higher one).

Most surveys have been interested in the Expected MRP, but this survey asks about the Required MRP. The paper also contains the references that professors use to justify their MRP, and comments from 180 professors that illustrate the various interpretations of what is the required MRP and explain the confusion of students and practitioners about its concept and magnitude.

We also report 416 answers from the field: the average MRP used by European Companies in 2008 was $6.4 \%$.

Classification JEL: G12, G31, M21

Keywords: equity premium puzzle; required equity premium; expected equity premium; historical equity premium.

\footnotetext{
${ }^{1}$ Professor, Financial Management, PricewaterhouseCoopers Chair of Finance, IESE
} 


\section{MARKET RISK PREMIUM USED BY PROFESSORS IN 2008: A SURVEY WITH 1,400 ANSWERS}

\section{Market Risk Premium (MRP) Used in 2008}

I sent a short email (see Exhibit 1) between January 9 and February 10, 2009 to about 7,500 email addresses of finance and economics professors obtained from previous correspondence, papers and universities' websites. I asked about the Market Risk Premium (MRP) "that we, professors, use to calculate the required return to equity" in 2008, in 2007 and in previous years. I also asked how the number was justified.

By April 2, 2009, I had received 1,309 responses from professors ${ }^{1}$ to which I added 96 answers provided by Ivo Welch from his 2009 survey. Of these 1,405 answers, 895 respondents provided a specific MRP used in $2008 .^{2}$

\footnotetext{
${ }^{1}$ I also received answers from companies, banks and investment banks. I will analyse them in a separate document.

2 I considered 11 of them as outliers because they provided a negative MRP (for example, $-39.96 \%$ and $-30 \%$ ) or a very high MRP (for example, 56\% and 41\%).
} 


\section{Table 1}

MRP used in 2008: 1,405 answers

\begin{tabular}{|c|c|c|c|c|c|c|c|c|}
\hline & & $\begin{array}{l}\text { United } \\
\text { States }\end{array}$ & Euro & $\begin{array}{r}\text { United } \\
\text { Kingdom }\end{array}$ & Canada & Australia & Other & Sum \\
\hline \multirow{4}{*}{$\begin{array}{l}\text { With a } \\
\text { number } \\
\text { for MRP } \\
\text { 2008: }\end{array}$} & reported & 487 & 224 & 54 & 29 & 23 & 67 & 884 \\
\hline & outliers & 5 & 2 & & 1 & 3 & & 11 \\
\hline & Different countries & 1 & 14 & 1 & 1 & 2 & 19 & 38 \\
\hline & Different universities/Business schools & 217 & 110 & 32 & 19 & 18 & 41 & 437 \\
\hline
\end{tabular}

Without a number for MRP 2008:

\begin{tabular}{|c|c|c|c|c|c|c|c|}
\hline "I do not use MRP, I think about premia for particular stocks" & 49 & 26 & 7 & 7 & 4 & 12 & 105 \\
\hline "I would tend to use whatever MRP is specified in the textbook" & 12 & 14 & 4 & 4 & 2 & 7 & 43 \\
\hline "I find that the CAPM is not very useful nor is the concept of MRP" & 36 & 29 & 8 & 1 & 4 & 7 & 85 \\
\hline "I did not have to use an estimate of the MRP in 2008" & 43 & 37 & 9 & 5 & 2 & 15 & 111 \\
\hline "I don't think about these things. I am an academic, not a practitioner" & 6 & 11 & 3 & & 3 & & 23 \\
\hline "I teach derivatives: I did not have to use a MRP" & 29 & 14 & 4 & 3 & 3 & & 53 \\
\hline "The MRP is not at all constant and changes every day" & 13 & 3 & 2 & 1 & 1 & 4 & 24 \\
\hline Other reasons & 28 & 9 & 7 & 3 & 2 & 17 & 66 \\
\hline SUM & 708 & 369 & 98 & 54 & 47 & 129 & 1,405 \\
\hline
\end{tabular}

Euro: Austria, Belgium, Denmark, Finland, France, Germany, Ireland, Italy, Netherlands, Norway, Portugal, Spain, Sweden and Switzerland

Australia: Australia and New Zealand.

Other: Argentina, Brazil, China, Czech Republic, Hong Kong, India, Iran, Israel, Japan, Mexico, Peru, Poland, Romania, Singapore, South Africa, Taiwan, Thailand, UA Emirates and Venezuela.

Table 2 contains the statistics of the MRP used in 2008. It is worth mentioning that the average MRP used by professors in the United States (6.3\%) was higher than the one used by their colleagues in Europe (5.3\%), Canada (5.4\%), United Kingdom (5.5\%) and Australia (5.9\%). ${ }^{3}$ There is a great dispersion in the MRP used by the professors of the same country.

${ }^{3} 129$ professors provided a range with an average wide of 1.9\%: I considered the medium point of the range.

2 - IESE Business School-University of Navarra 
Figure 1 is a graphic representation of the 884 MRP considered in Table 2.

\section{Table 2}

Market Risk Premium used in 2008 by 884 finance professors

\begin{tabular}{|c|c|c|c|c|c|c|c|c|}
\hline & & & & & & & \\
\hline & & United States & Euro & United Kingdom & Canada & Australia & Other & Sum \\
\hline \multirow{8}{*}{$\begin{array}{l}\text { MRP used } \\
\text { in } 2008\end{array}$} & Average & $6.3 \%$ & $5.3 \%$ & $5.5 \%$ & $5.4 \%$ & $5.9 \%$ & $7.9 \%$ & \multirow[b]{8}{*}{884} \\
\hline & St. dev. & $2.2 \%$ & $1.5 \%$ & $1.9 \%$ & $1.3 \%$ & $1.4 \%$ & $3.9 \%$ & \\
\hline & MAX & $19.0 \%$ & $10.0 \%$ & $10.0 \%$ & $8.0 \%$ & $7.5 \%$ & $27.0 \%$ & \\
\hline & Q3 & $7.2 \%$ & $6.0 \%$ & $7.0 \%$ & $6.0 \%$ & $7.0 \%$ & $10.0 \%$ & \\
\hline & Median & $6.0 \%$ & $5.0 \%$ & $5.0 \%$ & $5.1 \%$ & $6.0 \%$ & $7.0 \%$ & \\
\hline & Q1 & $5.0 \%$ & $4.1 \%$ & $4.0 \%$ & $5.0 \%$ & $6.0 \%$ & $5.5 \%$ & \\
\hline & $\min$ & $0.8 \%$ & $1.0 \%$ & $3.0 \%$ & $2.0 \%$ & $2.0 \%$ & $2.0 \%$ & \\
\hline & Number & 487 & 224 & 54 & 29 & 23 & 67 & \\
\hline \multicolumn{2}{|c|}{ I do not justify the number } & 93 & 53 & 20 & 6 & 2 & 21 & 195 \\
\hline \multicolumn{2}{|c|}{ Reference to books or articles } & 151 & 138 & 28 & 14 & 11 & 27 & 369 \\
\hline \multicolumn{2}{|c|}{ Historic Data } & 87 & 14 & 3 & 6 & 8 & 9 & 127 \\
\hline \multicolumn{2}{|c|}{ Own research/calculations } & 8 & 7 & 3 & 3 & 0 & 1 & 22 \\
\hline \multicolumn{2}{|c|}{ Do not answer } & 14 & 11 & 0 & 0 & 2 & 8 & 35 \\
\hline
\end{tabular}

\section{Figure 1}

Market Risk Premium used in 2008 by 884 finance professors
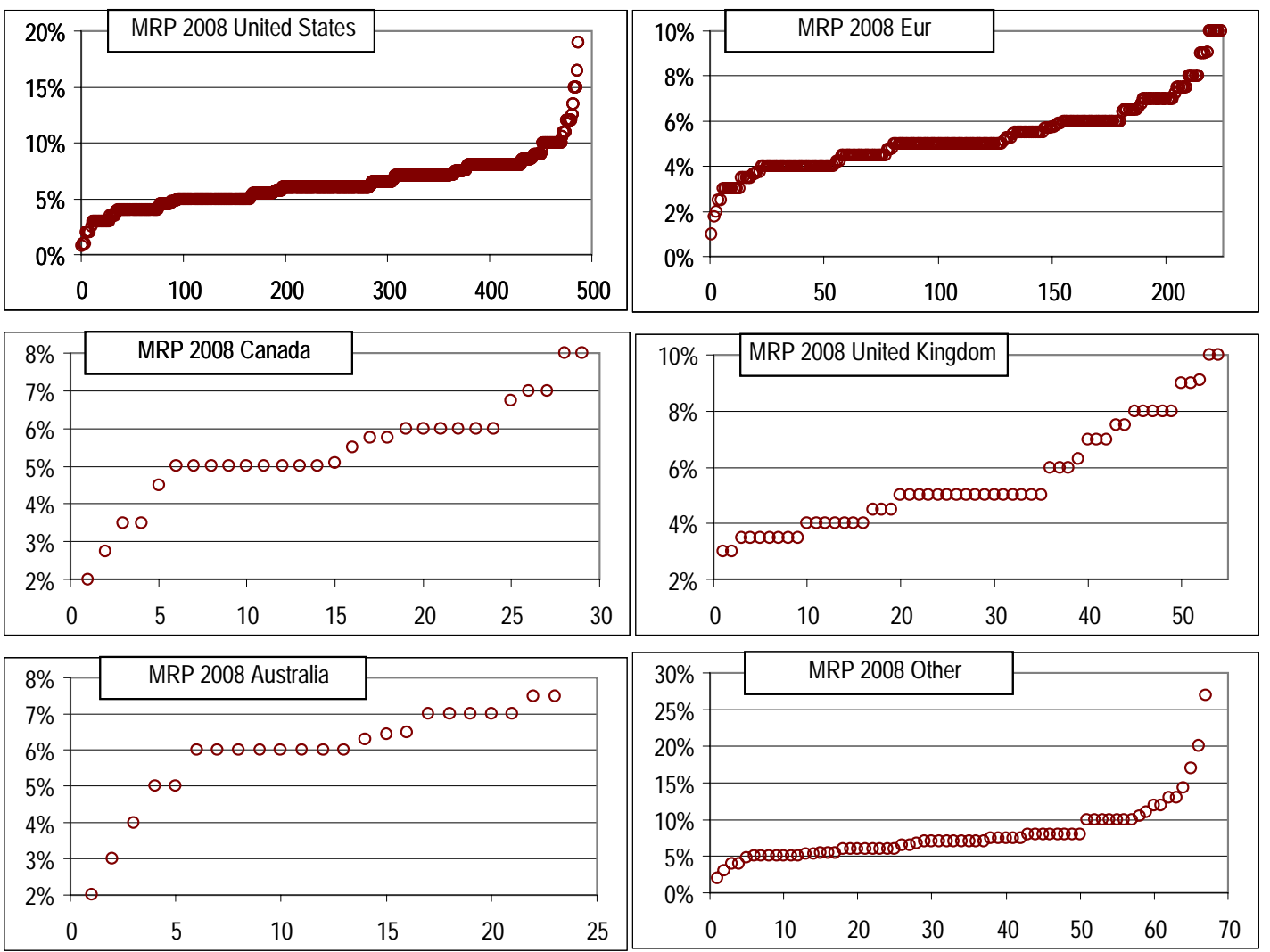


\section{Discrepancies of the MRP Used in 2008 by Professors of the Same Institution}

From 186 institutions, we got answers from two or more professors. Only 13 institutions had no discrepancy (dispersion) in the MRP used in 2008 by the professors who answered: 7 in the United States (6 with 2 respondents and 1 with 3 respondents), 3 in Europe (all with 2 respondents), 1 in Canada (2 respondents), 1 in India (2 respondents) and 1 in Singapore (3 respondents). Another 13 institutions (all with 2 respondents) had dispersion smaller than 0.9\%: 8 in Europe, 3 in United States, 1 in Canada and 1 in United Kingdom. Table 3 shows that the dispersion increases, on average, with the number of respondents.

\section{Table 3}

Dispersion of the Market Risk Premium used in 2008 by professors of the same School / University. MRP Max - MRP min used in 2008. Results grouped by the number of professors that answered from the same institution

\begin{tabular}{|l|r|r|r|r|r|r|}
\cline { 5 - 7 } \multicolumn{2}{c|}{} & \multicolumn{5}{c|}{ MRP Max - MRP min used in 2008 } \\
\hline $\begin{array}{l}\text { Number of answers from } \\
\text { the same institution }\end{array}$ & $\begin{array}{l}\text { Number of } \\
\text { institutions }\end{array}$ & Max & Min & Average & Median & St. dev. \\
\hline 2 & 80 & $11,0 \%$ & $0,0 \%$ & $2,6 \%$ & $2,0 \%$ & $2,6 \%$ \\
\hline 3 & 45 & $8,5 \%$ & $0,0 \%$ & $3,3 \%$ & $3,0 \%$ & $2,0 \%$ \\
\hline 4 & 25 & $9,5 \%$ & $0,9 \%$ & $3,8 \%$ & $3,0 \%$ & $2,3 \%$ \\
\hline 5 & 13 & $8,0 \%$ & $1,0 \%$ & $4,2 \%$ & $4,0 \%$ & $2,0 \%$ \\
\hline 6 & 6 & $6,0 \%$ & $2,0 \%$ & $3,7 \%$ & $3,5 \%$ & $1,6 \%$ \\
\hline 7 & 8 & $7,0 \%$ & $2,0 \%$ & $5,0 \%$ & $6,0 \%$ & $1,8 \%$ \\
\hline 8 & 2 & $7,0 \%$ & $7,0 \%$ & $7,0 \%$ & $7,0 \%$ & $0,0 \%$ \\
\hline 9 & 4 & $9,0 \%$ & $3,5 \%$ & $5,6 \%$ & $5,0 \%$ & $2,5 \%$ \\
\hline 11 & 1 & & & $6,0 \%$ & $6,0 \%$ & \\
\hline 12 & 1 & & & $23,0 \%$ & $23,0 \%$ & \\
\hline 14 & 1 & & & $9,0 \%$ & $9,0 \%$ & \\
\hline
\end{tabular}

For example, the 9 answers from a European Business School were: 4\%, 5\% (4 professors), 5.12\%, 5.5\%, 6\% and 7.5\%. The 14 answers from a United States Business School were: 3\%, 3-6\%, 4\%, $6 \%$ (4 professors), 4-8\%, 8\% (4 professors), 10\%, and 12\%. The 2 answers from another United States Business School were: 4\% and 13.5\%. Figures 2 and 3 contain the dispersion of the answers from European, United Kingdom and United States institutions. Table 4 shows that the maximum average dispersion corresponded to the United States. 
Figure 2

Dispersion of the MRP used in 2008 by professors of the same institution in Europe and United Kingdom. 58 institutions

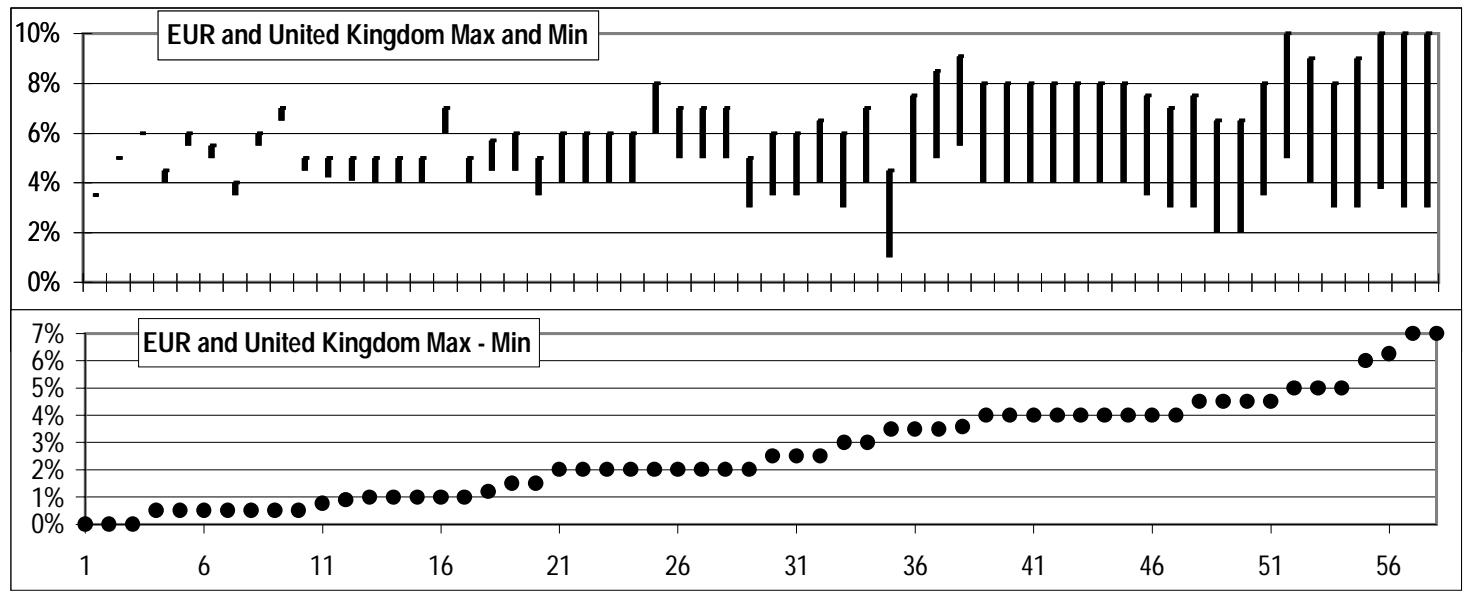

Figure 3

Dispersion of the MRP used in 2008 by professors of the same institution in the United States. 103 institutions.

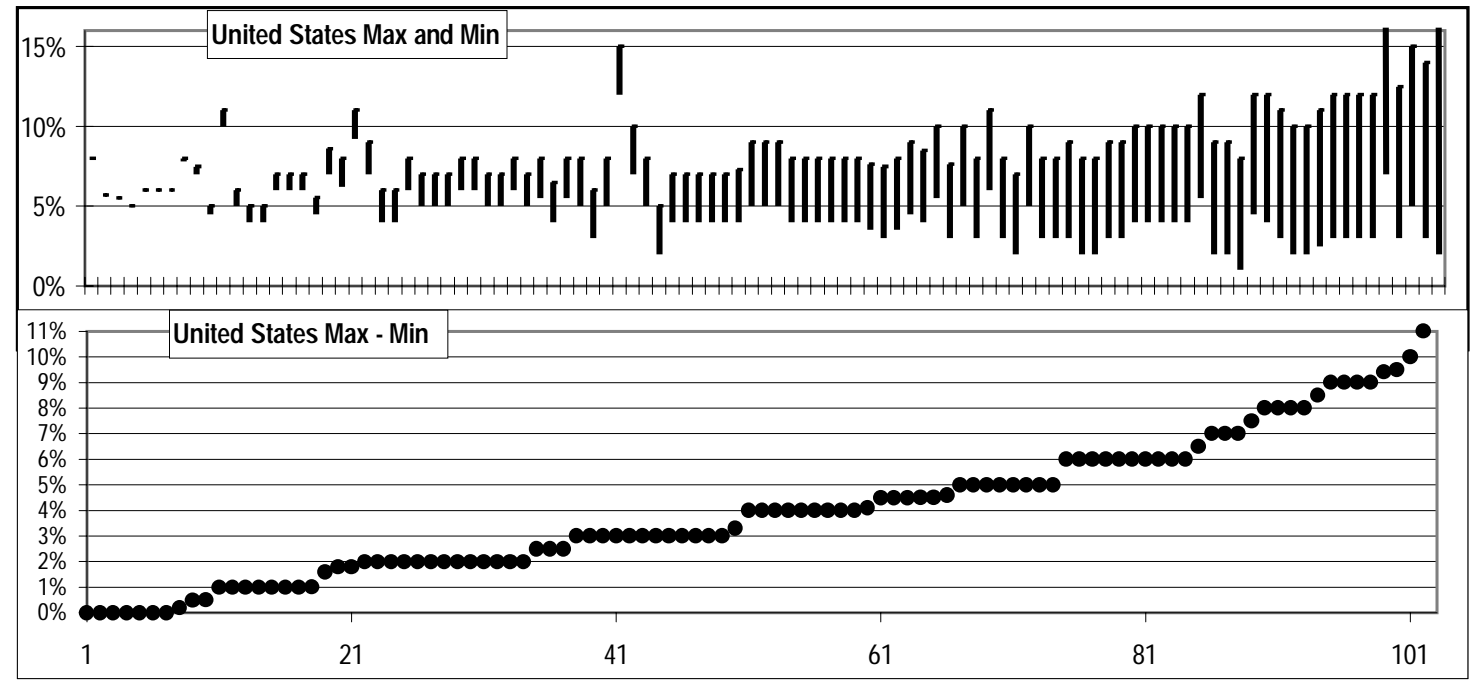




\section{Table 4}

Dispersion of the Market Risk Premium used in 2008 by professors of the same School / University. MRP Max - MRP Min used in 2008

\begin{tabular}{|c|c|c|c|c|c|c|c|}
\hline & United States & Euro & United Kingdom & Canada & Australia & Other & All \\
\hline Max & $23,0 \%$ & $7,0 \%$ & $7,0 \%$ & $4,5 \%$ & $5,0 \%$ & $6,0 \%$ & $23,0 \%$ \\
\hline Min & $0,0 \%$ & $0,0 \%$ & $0,5 \%$ & $0,0 \%$ & $2,0 \%$ & $0,0 \%$ & $0,0 \%$ \\
\hline Average & $4,2 \%$ & $2,5 \%$ & $3,5 \%$ & $2,4 \%$ & $3,0 \%$ & $2,3 \%$ & $3,5 \%$ \\
\hline Median & $4,0 \%$ & $2,0 \%$ & $4,0 \%$ & $2,5 \%$ & $2,0 \%$ & $1,8 \%$ & $3,0 \%$ \\
\hline St. dev. & $3,3 \%$ & $1,8 \%$ & $2,1 \%$ & $1,7 \%$ & $1,7 \%$ & $2,0 \%$ & $2,8 \%$ \\
\hline Number of schools & 103 & 48 & 10 & 8 & 3 & 14 & 186 \\
\hline Number of professors & 382 & 157 & 36 & 18 & 11 & 37 & 641 \\
\hline
\end{tabular}

\section{MRP Used by Professors in 2008 and in 2007}

600 professors indicated which MRP they used in 2007. Table 5 compares it with the MRP used in 2008:

- $15 \%$ of the professors decreased the MRP in 2008 (1.5\% on average)

- $61 \%$ used the same MRP, and

- $24 \%$ increased it (2\% on average).

\section{Table 5}

MRP used in 2008 - MRP used in 2007

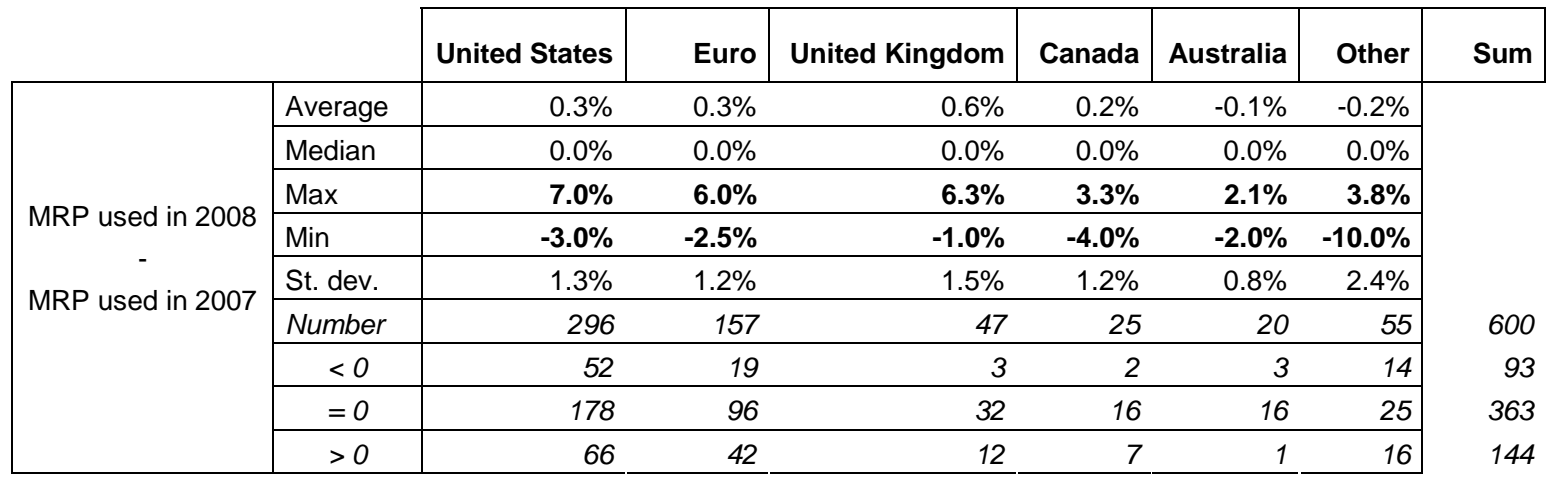
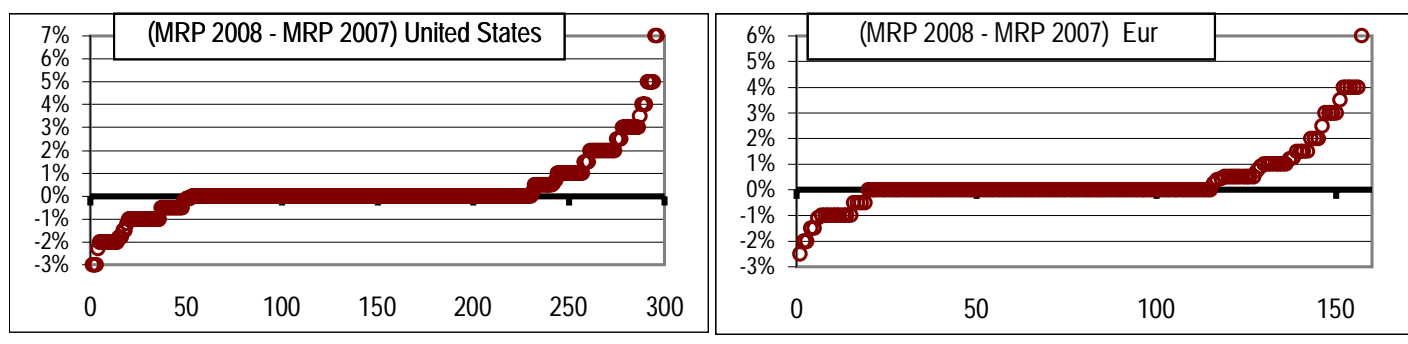

$66 \%$ of the professors report that they used a lower MRP in 2007 than in 2000 (22\% used a higher one). The average MRP used in 2007 was 1.5\% lower than the one used in 2000. 


\section{MRP Ised by Professors in 2008: a Closer Look by Country}

Table 6 contains the statistics by country of the MRP used in 2008. We only report statistics for the 18 countries with 6 or more answers. The average MRP used by professors in the United States (6.3\%) was higher than the one used by their colleagues in any European country.

\section{Table 6}

Market Risk Premium used in 2008 by professors of 18 different countries

\begin{tabular}{|c|c|c|c|c|c|c|c|c|}
\hline & $\begin{array}{l}\text { Number of } \\
\text { professors }\end{array}$ & Average & St. dev. & $\operatorname{Max}$ & Q3 & Median & Q1 & Min \\
\hline France & 30 & $5,9 \%$ & $2,0 \%$ & $10,0 \%$ & $7,2 \%$ & $5,8 \%$ & $5,0 \%$ & $1,8 \%$ \\
\hline Portugal & 6 & $5,9 \%$ & $1,0 \%$ & $7,0 \%$ & $6,9 \%$ & $5,8 \%$ & $5,1 \%$ & $5,0 \%$ \\
\hline Switzerland & 10 & $5,6 \%$ & $1,4 \%$ & $7,5 \%$ & $6,9 \%$ & $5,5 \%$ & $4,5 \%$ & $4,0 \%$ \\
\hline Norway & 9 & $5,6 \%$ & $1,6 \%$ & $9,0 \%$ & $6,5 \%$ & $5,0 \%$ & $5,0 \%$ & $4,0 \%$ \\
\hline Spain & 70 & $5,4 \%$ & $1,5 \%$ & $10,0 \%$ & $6,0 \%$ & $5,0 \%$ & $4,5 \%$ & $2,0 \%$ \\
\hline Netherlands & 23 & $5,3 \%$ & $1,5 \%$ & $10,0 \%$ & $6,0 \%$ & $5,5 \%$ & $4,5 \%$ & $3,0 \%$ \\
\hline Finland & 9 & $5,3 \%$ & $1,9 \%$ & $10,0 \%$ & $5,8 \%$ & $4,5 \%$ & $4,0 \%$ & $4,0 \%$ \\
\hline Italy & 23 & $4,9 \%$ & $1,5 \%$ & $10,0 \%$ & $5,6 \%$ & $5,0 \%$ & $4,0 \%$ & $3,0 \%$ \\
\hline Germany & 26 & $4,8 \%$ & $1,3 \%$ & $7,5 \%$ & $5,5 \%$ & $4,9 \%$ & $4,0 \%$ & $1,0 \%$ \\
\hline Belgium & 6 & $4,1 \%$ & $0,8 \%$ & $5,5 \%$ & $4,4 \%$ & $3,9 \%$ & $3,6 \%$ & $3,5 \%$ \\
\hline United Kingdom & 54 & $5,5 \%$ & $1,9 \%$ & $10,0 \%$ & $7,0 \%$ & $5,0 \%$ & $4,0 \%$ & $3,0 \%$ \\
\hline Canada & 29 & $5,4 \%$ & $1,3 \%$ & $8,0 \%$ & $6,0 \%$ & $5,1 \%$ & $5,0 \%$ & $2,0 \%$ \\
\hline United States & 487 & $6,3 \%$ & $2,2 \%$ & $19,0 \%$ & $7,2 \%$ & $6,0 \%$ & $5,0 \%$ & $0,8 \%$ \\
\hline Australia & 23 & $5,9 \%$ & $1,4 \%$ & $7,5 \%$ & $7,0 \%$ & $6,0 \%$ & $6,0 \%$ & $2,0 \%$ \\
\hline India & 10 & $10,5 \%$ & $4,4 \%$ & $20,0 \%$ & $10,8 \%$ & $8,0 \%$ & $8,0 \%$ & $7,0 \%$ \\
\hline Israel & 9 & $7,3 \%$ & $3,1 \%$ & $12,0 \%$ & $10,0 \%$ & $7,5 \%$ & $5,0 \%$ & $2,0 \%$ \\
\hline Singapore & 7 & $6,6 \%$ & $1,7 \%$ & $10,0 \%$ & $7,0 \%$ & $6,5 \%$ & $5,5 \%$ & $5,0 \%$ \\
\hline China & 7 & $6,3 \%$ & $1,9 \%$ & $10,0 \%$ & $6,8 \%$ & $5,5 \%$ & $5,2 \%$ & $5,0 \%$ \\
\hline
\end{tabular}

\section{References used to justify the MRP figure}

389 professors indicated which books or papers they use as reference to justify the MRP that they use (95 of them provided more than one reference). Table 7 contains the most cited references and Figure 4 contains the dispersion of the MRP used in 2008 by the professors who cited the most popular references: Ibbotson, Dimson el al, Damodaran and Brealey and Myers. 


\section{Table 7}

References to justify the Market Risk Premium used

\begin{tabular}{|l|r|r|r|r|r|r|r|}
\cline { 2 - 7 } \multicolumn{1}{c|}{ References } & United States & Euro & United Kingdom & Canada & Australia & Other & Sum \\
\hline Ibbotson & 53 & 9 & 3 & 2 & 1 & 3 & 71 \\
\hline Dimson, Marsh and Staunton & 11 & 23 & 9 & 1 & 4 & 1 & 49 \\
\hline Damodaran & 15 & 21 & 0 & 2 & 1 & 3 & 42 \\
\hline Brealey and Myers & 16 & 12 & 2 & 0 & 1 & 4 & 35 \\
\hline Fernández & 3 & 18 & 1 & 0 & 0 & 0 & 22 \\
\hline Fama and French, 2002 & 9 & 5 & 3 & 2 & 1 & 1 & 21 \\
\hline Welch & 4 & 7 & 5 & 2 & 1 & 0 & 19 \\
\hline Ross, Westerfield and Jaffe/Jordan & 7 & 2 & 1 & 2 & 0 & 1 & 13 \\
\hline Mehra Prescott & 4 & 3 & 1 & 1 & 2 & 2 & 13 \\
\hline Investment banks/consult & 1 & 6 & 2 & 1 & 0 & 0 & 10 \\
\hline Copeland (McKinsey) & 3 & 6 & 0 & 0 & 0 & 0 & 9 \\
\hline Siegel & 4 & 3 & 0 & 0 & 1 & 1 & 9 \\
\hline Bodie, Kane and Marcus & 5 & 3 & 0 & 1 & 0 & 0 & 9 \\
\hline Claus and Thomas & 4 & 3 & 1 & 0 & 0 & 0 & 8 \\
\hline Associes en Finance & 0 & 7 & 0 & 0 & 0 & 0 & 7 \\
\hline Brigham et al & 5 & 0 & 0 & 0 & 0 & 2 & 7 \\
\hline Goetzman and Jorion & 4 & 1 & 1 & 0 & 0 & 0 & 6 \\
\hline Cornell book & 3 & 1 & 0 & 0 & 1 & 0 & 5 \\
\hline The Wall Street Journal & 4 & 0 & 0 & 0 & 0 & 0 & 4 \\
\hline Other & 209 & 178 & 98 & 23 & 25 & 33 & 501 \\
\hline Total & & & 9 & 12 & 15 & 142 \\
\hline
\end{tabular}

\section{Figure 4}

Dispersion of the MRP used in 2008 by the professors who cited the most popular references: Ibbotson, Dimson et al., Damodaran and Brealey and Myers
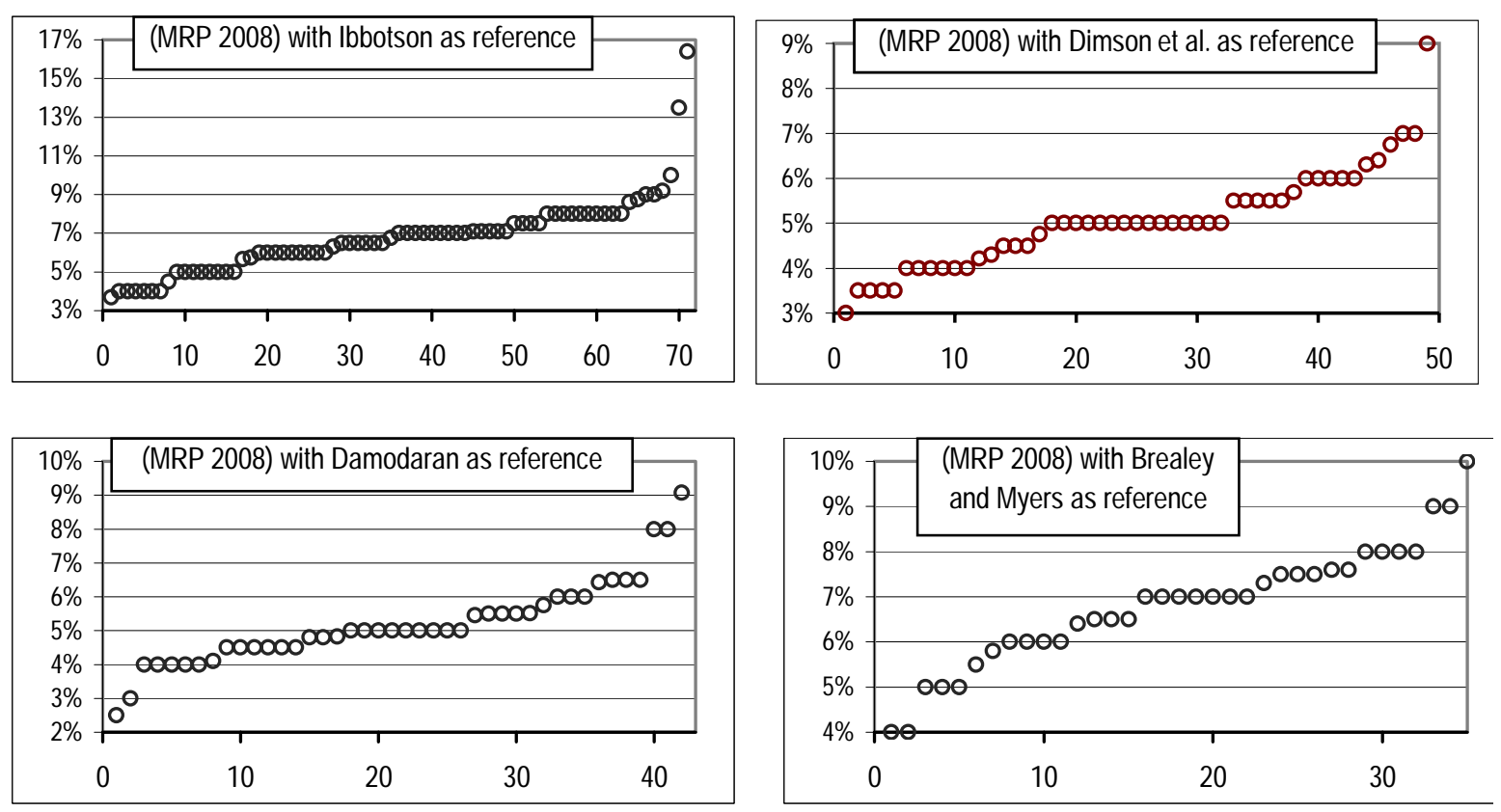


\section{Table 8}

Differences in the Market Risk Premium used by different professors

\begin{tabular}{|c|c|c|c|c|c|c|c|c|c|}
\hline & & & United States & Euro & United Kingdom & Canada & Australia & Other & Sum \\
\hline \multirow{9}{*}{$\begin{array}{l}\text { MRP used } \\
\text { in } 2008\end{array}$} & \multirow{3}{*}{$\begin{array}{l}\text { I do not } \\
\text { justify the } \\
\text { number }\end{array}$} & Average & $7.1 \%$ & $5.5 \%$ & $5.4 \%$ & $5.3 \%$ & $5.0 \%$ & $9.0 \%$ & \\
\hline & & St. dev. & $2.6 \%$ & $1.8 \%$ & $1.7 \%$ & $0.5 \%$ & $1.4 \%$ & $5.2 \%$ & \\
\hline & & Number & 92 & 52 & 19 & 6 & 2 & 21 & 192 \\
\hline & \multirow{3}{*}{$\begin{array}{l}\text { Reference } \\
\text { to books } \\
\text { or articles }\end{array}$} & Average & $6.1 \%$ & $5.3 \%$ & $5.3 \%$ & $5.5 \%$ & $5.6 \%$ & $7.4 \%$ & \\
\hline & & St. dev. & $2.0 \%$ & $1.4 \%$ & $1.7 \%$ & $1.2 \%$ & $1.7 \%$ & $2.6 \%$ & \\
\hline & & Number & 150 & 136 & 28 & 14 & 11 & 27 & 366 \\
\hline & \multirow{3}{*}{$\begin{array}{l}\text { Historic } \\
\text { Data }\end{array}$} & Average & $6.8 \%$ & $6.0 \%$ & $8.6 \%$ & $5.6 \%$ & $6.4 \%$ & $7.2 \%$ & \\
\hline & & St. dev. & $1.6 \%$ & $1.4 \%$ & $0.8 \%$ & $1.8 \%$ & $0.5 \%$ & $2.2 \%$ & \\
\hline & & Number & 87 & 14 & 2 & 6 & 8 & 9 & 126 \\
\hline
\end{tabular}

\section{Comparison with Previous Surveys}

Welch (2000) performed two surveys with finance professors in 1997 and 1998, asking them what they thought the Expected MRP would be over the next 30 years. He obtained 226 replies, ranging from 1\% to 15\%, with an average arithmetic EEP of 7\% above T-Bonds. ${ }^{4}$ Welch (2001) presented the results of a survey of 510 finance and economics professors performed in August 2001 and the consensus for the 30-year arithmetic EEP was 5.5\%; much lower than just 3 years earlier. In an update published in 2008 Welch reports that the MRP "used in class" in December 2007 by about 400 finance professors was on average 5.89\%, and 90\% of the professors used equity premia between $4 \%$ and $8.5 \%$.

Table 9 compares the main results of Ivo Welch's surveys with some results of Table 2.

\section{Table 9}

Comparison of the Ivo Welch's surveys with this one

\begin{tabular}{|c|c|c|c|c|c|c|c|}
\hline & \multicolumn{5}{|c|}{ Ivo Welch's surveys } & \multicolumn{2}{|c|}{ This survey (Jan 09) } \\
\hline & Oct $97-$ Feb $98^{*}$ & Jan-May $99^{+}$ & Sep $2001^{* *}$ & Dec. 2007\# & January $2009^{++}$ & United States & Europe \\
\hline Number of answers & 226 & 112 & 510 & 360 & 143 & 487 & 224 \\
\hline Average & $7.2 \%$ & $6.8 \%$ & $4.7 \%$ & $5.96 \%$ & $6.2 \%$ & $6.3 \%$ & $5.3 \%$ \\
\hline Std. dev. & $2.0 \%$ & $2.0 \%$ & $2.2 \%$ & $1.7 \%$ & $1.7 \%$ & $2.2 \%$ & $1.5 \%$ \\
\hline Max & $15 \%$ & $15 \%$ & 20 & $20 \%$ & & $19.0 \%$ & $10.0 \%$ \\
\hline Q3 & $8.4 \%$ & $8 \%$ & $6 \%$ & $7.0 \%$ & $7 \%$ & $7.2 \%$ & $6.0 \%$ \\
\hline Median & $7 \%$ & $7 \%$ & $4.5 \%$ & $6.0 \%$ & $6 \%$ & $6.0 \%$ & $5.0 \%$ \\
\hline Q1 & $6 \%$ & $5 \%$ & $3 \%$ & $5.0 \%$ & $5 \%$ & $5.0 \%$ & $4.1 \%$ \\
\hline Min & $1.5 \%$ & $1.5 \%$ & $0 \%$ & $2 \%$ & & $0.8 \%$ & $1.0 \%$ \\
\hline
\end{tabular}

* 30-Year Forecast. Welch (2000) First survey

+ 30-Year Forecast. Welch (2000) Second survey

** 30 year Equity Premium Forecast (Geometric). “The Equity Premium Consensus Forecast Revisited” (2001)

\# 30-Year Geo Eq Prem Used in class. Welch, I. (2008), "The Consensus Estimate for the Equity Premium by Academic Financial Economists in December 2007". http://ssrn.com/abstract=1084918

++ In your classes, what is the main number you are recommending for long-term CAPM purposes? "Short Academic Equity Premium Survey for January 2009”. http://welch.econ.brown.edu/academics/equpdate-results2009.html

\footnotetext{
4 At that time, the most recent Ibbotson Associates Yearbook reported an arithmetic HEP versus T-bills of 8.9\% (1926-1997).
} 
Johnson et al. (2007) report the results of a survey of 116 finance professors in North America done in March 2007: 90\% of the professors believed the Expected MRP during the next 30 years to range from $3 \%$ to $7 \%$.

Graham and Harvey (2007) indicate that United States CFOs reduced their average EEP from $4.65 \%$ in September 2000 to $2.93 \%$ by September 2006 (st. dev. of the 465 responses $=2.47 \%$ ). In the 2008 survey, they report an average EEP of 3.80\%, ranging from 3.1\% to $11.5 \%$ at the tenth percentile at each end of the spectrum. They show that average EEP changes through time. Goldman Sachs (O'Neill, Wilson and Masih, 2002) conducted a survey of its global clients in July 2002 and the average long-run EEP was 3.9\%, with most responses between 3.5\% and 4.5\%. The magazine Pensions and Investments (12/1/1998) carried out a survey among professionals working for institutional investors: the average EEP was 3\%. Shiller ${ }^{5}$ publishes and updates an index of investor sentiment since the crash of 1987. While neither survey provides a direct measure of the equity risk premium, they yield a broad measure of where investors or professors expect stock prices to go in the near future. The 2004 survey of the Securities Industry Association (SIA) found that the median EEP of 1500 United States investors was about 8.3\%. Merrill Lynch surveys more than 300 institutional investors globally in July 2008: the average EEP was 3.5\%.

\section{Table 10}

Estimates of the EEP (Expected Equity Premium) according to other surveys

\begin{tabular}{|lcc|}
\hline Authors & Conclusion about EEP & Respondents \\
\hline Pensions and Investments (1998) & $3 \%$ & Institutional investors \\
Graham and Harvey (2007) & Sep. 2000. Mean: 4.65\%. Std. Dev. $=2.7 \%$ & CFOs \\
Graham and Harvey (2007) & Sep. 2006. Mean: 2.93\%. Std. Dev. $=2.47 \%$ & CFOs \\
Welch update & December 2007. Mean: 5.69\%. Range 2\% to 12\% & Finance professors \\
O'Neill, Wilson and Masih (2002) & $3.9 \%$ & Global clients Goldman \\
\hline
\end{tabular}

Ilmanen (2003) argues that surveys tend to be optimistic: "survey-based expected returns may tell us more about hoped-for returns than about required returns." Damodaran (2008) points out that "the risk premiums in academic surveys indicate how far removed most academics are from the real world of valuation and corporate finance and how much of their own thinking is framed by the historical risk premiums... The risk premiums that are presented in classroom settings are not only much higher than the risk premiums in practice but also contradict other academic research".

A main difference of this survey with previous ones is that this survey asks about the Required MRP, while most surveys are interested in the Expected MRP. This survey also compares United States with Europe and other parts of the world, contains the references that professors use to justify their MRP and includes comments from 180 professors (see Exhibits 2 and 3).

\footnotetext{
${ }^{5}$ See http://icf.som.yale.edu/Confidence.Index

10 - IESE Business School-University of Navarra
} 


\section{Relationship of the Results of the Survey with the Recommendations of Finance Textbooks}

Fernandez (2008) reviews 100 textbooks on corporate finance and valuation published between 1979 and 2008 by authors such as Brealey and Myers, Copeland, Damodaran, Merton, Ross, Bruner... and finds that their recommendations regarding the equity premium range from $3 \%$ to $10 \%$, and that 28 books use different equity premia in various pages. Figure 5 contains the evolution of the Required Equity Premium (REP) used or recommended by the books, and helps to explain the confusion that exists about the equity premium.

\section{Figure 5}

Evolution of the Required Equity Premium (REP) used or recommended in 100 finance and valuation textbooks.

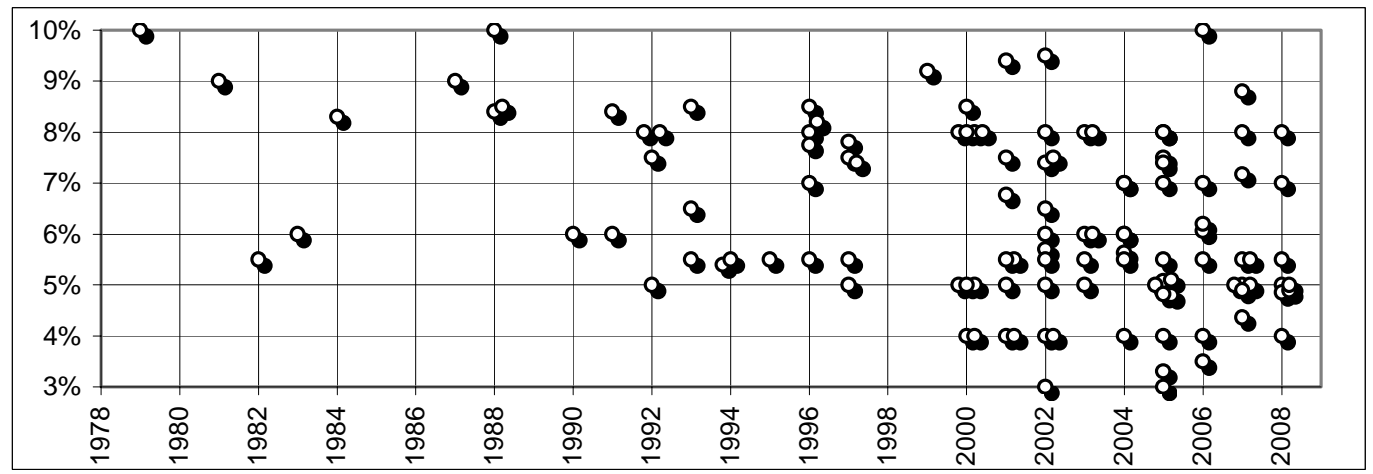

Source: Fernández (2008).

Figure 6 contains the moving average of the recommendations in Figure 5 which is in line with the findings of Welch (see table 9) and with the results of this survey.

\section{Figure 6}

Average of the Required Equity Premium (REP) used or recommended in 100 finance and valuation textbooks.

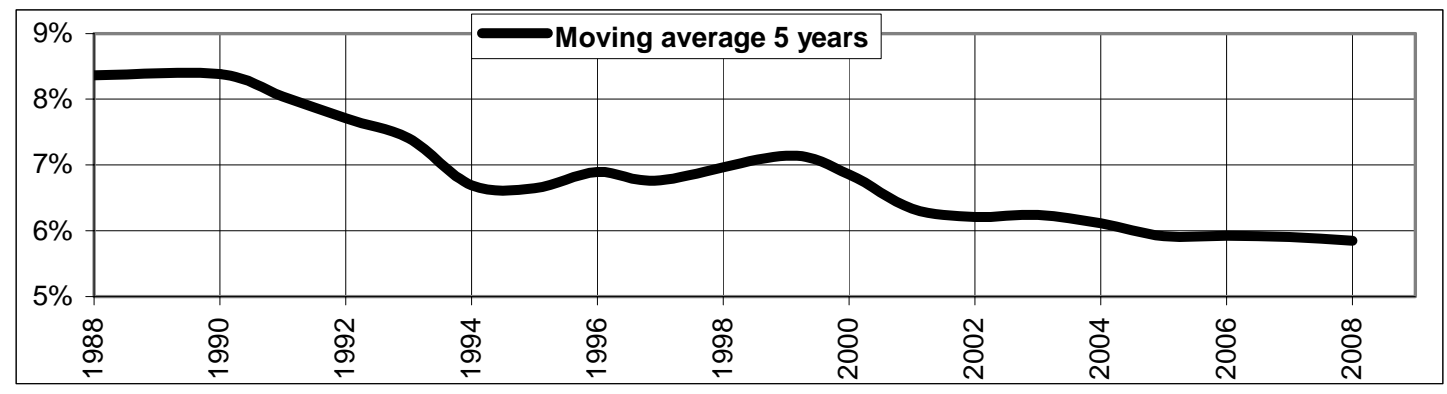

Source: Fernandez (2008) 


\section{MRP or EP (Equity Premium): Four Different Concepts}

As Fernandez (2007) claims, the term "equity premium" is used to designate four different concepts:

1. Historical equity premium (HEP): historical differential return of the stock market over treasuries.

2. Expected equity premium (EEP): expected differential return of the stock market over treasuries.

3. Required equity premium (REP): incremental return of a diversified portfolio (the market) over the risk-free rate required by an investor. It is used for calculating the required return to equity.

4. Implied equity premium (IEP): the required equity premium that arises from assuming that the market price is correct.

The four concepts (HEP, REP, EEP and IEP) designate different realities. The HEP is easy to calculate and is equal for all investors, provided they use the same time frame, the same market index, the same risk-free instrument and the same average (arithmetic or geometric). But the EEP, the REP and the IEP may be different for different investors and are not observable.

The HEP is the historical average differential return of the market portfolio over the risk-free debt. The most widely cited sources are Ibbotson Associates and Dimson et al. (2007).

Numerous papers and books assert or imply that there is a "market" EEP. However, it is obvious that investors and professors do not share "homogeneous expectations" and have different assessments of the EEP. As Brealey et al. (2005, page 154) affirm, "Do not trust anyone who claims to know what returns investors expect".

The REP is the answer to the following question: What incremental return do I require for investing in a diversified portfolio of shares over the risk-free rate? It is a crucial parameter because the REP is the key to determining the company's required return to equity and the WACC. Different companies may use, and in fact do use, different REPs.

The IEP is the implicit REP used in the valuation of a stock (or market index) that matches the current market price. The most widely used model to calculate the IEP is the dividend discount model: the current price per share $\left(\mathrm{P}_{0}\right)$ is the present value of expected dividends discounted at the required rate of return (Ke). If $d_{1}$ is the dividend per share expected to be received at time 1 , and $g$ the expected long term growth rate in dividends per share,

$$
\mathrm{P}_{0}=\mathrm{d}_{1} /(\mathrm{Ke}-\mathrm{g}) \text {, which implies: IEP }=\mathrm{d}_{1} / \mathrm{P}_{0}+\mathrm{g}-\mathrm{R}_{\mathrm{F}}
$$

The estimates of the IEP depend on the particular assumption made for the expected growth (g). Even if market prices are correct for all investors, there is no common IEP for all investors: there are many pairs (IEP, g) that accomplish equation (1). Even if equation (1) holds for every investor, there are many required returns (as many as expected growths, g) in the market. Many papers in the financial literature report different estimates of the IEP with great dispersion, as for example, Claus and Thomas (2001, IEP $=3 \%)$, Harris and Marston $(2001$, IEP $=7.14 \%$ ) and Ritter and Warr (2002, IEP $=12 \%$ in 1980 and $-2 \%$ in 1999). There is no common IEP for all investors. 
For a particular investor, the EEP is not necessary equal to the REP (unless he considers that the market price is equal to the value of the shares). Obviously, an investor will hold a diversified portfolio of shares if his EEP is higher (or equal) than his REP and will not hold it otherwise.

We can find out the REP and the EEP of an investor by asking him, although for many investors the REP is not an explicit parameter but, rather, it is implicit in the price they are prepared to pay for the shares. However, it is not possible to determine the REP for the market as a whole, because it does not exist: even if we knew the REPs of all the investors in the market, it would be meaningless to talk of a REP for the market as a whole. There is a distribution of REPs and we can only say that some percentage of investors have REPs contained in a range. The average of that distribution cannot be interpreted as the REP of the market nor as the REP of a representative investor.

Much confusion arises from not distinguishing among the four concepts that the phrase equity premium designates: Historical equity premium, Expected equity premium, Required equity premium and Implied equity premium. 88 of the books reviewed by Fernández (2008) identify Expected and Required equity premium and 59 books identify Expected and Historical equity premium.

Finance textbooks should clarify the MRP by incorporating distinguishing definitions of the four different concepts and conveying a clearer message about their sensible magnitudes.

\section{MRP used in 2008 by European Companies}

Table 11 summarizes the 416 answers from European Companies to a survey asking the MRP "used to calculate the required return to equity" in 2008. Figure 7 is a graphic representation of the 234 MRP reported. The average MRP used by European Companies in 2008 was $6.4 \%{ }^{6}$. This average is close to the one used by United States professors (6.3\%), but higher than the one used by professors in Europe (5.3\%).

\footnotetext{
${ }^{6}$ If we consider as outliers the 7 answers over $15 \%$, the average is $5.9 \%$.
} 


\section{Table 11}

Market Risk Premium used in 2008 by European companies: 416 answers

\begin{tabular}{|l|r|rrr|r|}
\cline { 2 - 6 } \multicolumn{1}{c|}{} & Number & Maximum & Minimum & Average & St. dev. \\
\hline Companies that use MRP & $\mathbf{2 3 4}$ & $30.0 \%$ & $2.0 \%$ & $\mathbf{6 . 4} \%$ & $3.8 \%$ \\
European & 169 & $30.0 \%$ & $2.0 \%$ & $6.3 \%$ & $3.9 \%$ \\
European Branch of a Multinational & 65 & $17.5 \%$ & $3.0 \%$ & $6.5 \%$ & $3.6 \%$ \\
& & & & & \\
We do not justify the number & 40 & $20.0 \%$ & $2.5 \%$ & $6.6 \%$ & $3.5 \%$ \\
Reference to books or articles & 106 & $12.0 \%$ & $2.0 \%$ & $5.1 \%$ & $\mathbf{1 . 1} \%$ \\
Headquarters or the owner fix the number & 73 & $30.0 \%$ & $2.0 \%$ & $\mathbf{8 . 4} \%$ & $5.6 \%$ \\
Analysts & 15 & $5.5 \%$ & $4.0 \%$ & $4.8 \%$ & $\mathbf{0 . 4 \%}$ \\
\hline
\end{tabular}

\begin{tabular}{|cr|}
\hline Companies that do NOT use MRP & 153 \\
Use a minimum IRR & 64 \\
Use a required return to equity & 6 \\
Use other criteria & 14 \\
"MRP is a concept that we do not use" & 69 \\
\hline
\end{tabular}

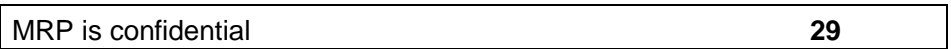

TOTAL companies

416

Figure 7

Market Risk Premium used in 2008 by 234 European companies

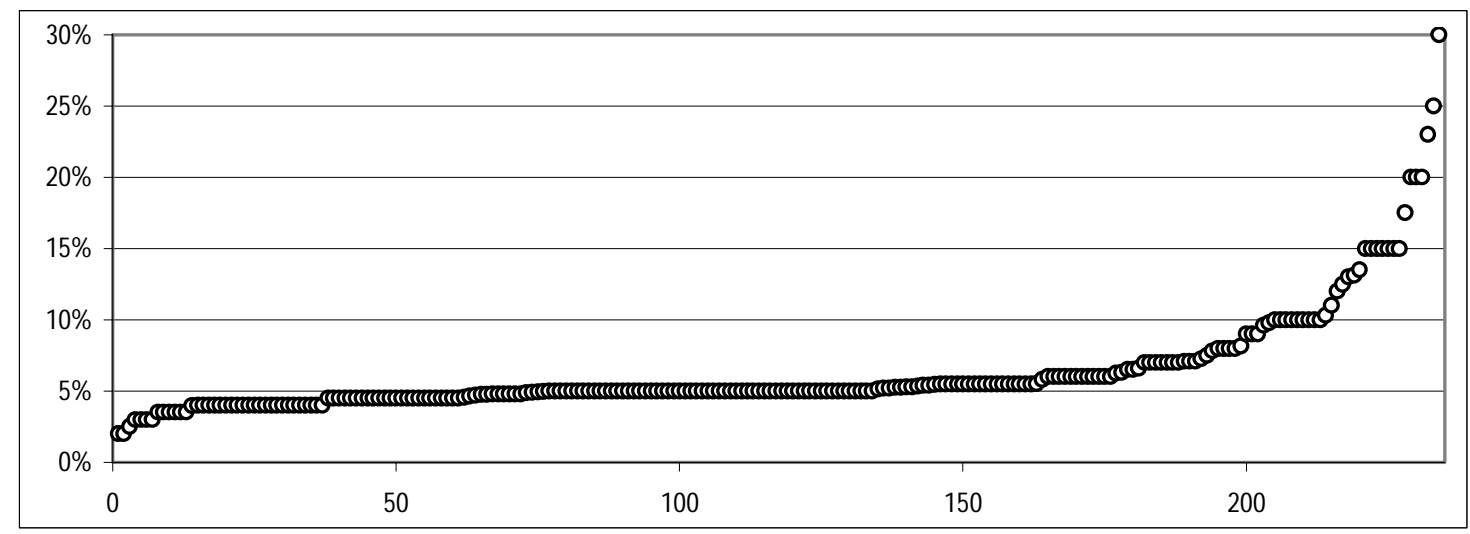

The most relevant results of the survey were:

1. Great dispersion: companies used MRP between 2 and 30\%. Figure 7 highlights this fact.

2. Banks and financial companies had a smaller dispersion: they used MRP between $2 \%$ and $8.2 \%{ }^{7}$

\footnotetext{
${ }^{7}$ The average of the 52 answers from Banks and Financial Co. was 5.1\% and the standard deviation 1.1\%. 
3. Many companies (153) do not use a MRP. Some of these use a minimum IRR or a minimum required return to equity. Other use other criteria such as ebitda/sales, gross margin/sales and PE Ratio.

\section{Conclusion}

Most surveys have been interested in the Expected MRP, but this survey asks about the Required MRP.

There is a lack of consensus among professors about the magnitude of the MRP: the dispersion of the MRP used was high: the average MRP used by professors of the same institution range was 3.5\% and the one of the same country was 6.9\%. The average MRP used in 2008 in 18 different countries ranges from 4.1\% (Belgium) to 10.5\% (India).

There is also a great dispersion in the MRP used in 2008 by the professors who cited the same reference to justify the MRP that they use. Professors who cited Ibbotson as their reference used MRP between 3.5\% and 16.5\%; professors who cited Dimson et al as their reference used MRP between 3\% and 9\%; professors who cited Damodaran as their reference used MRP between 2.5\% and 9\%; and professors who cited Brealey and Myers as their reference used MRP between $4 \%$ and $10 \%$.

There is also a great dispersion in the MRP used in 2008 by 416 European Companies: a MRP of between 2 and 30\% was used. The average MRP used by European Co. was 6.4\%, close to the one used by United States professors (6.3\%), but higher than the one used by professors in Europe (5.3\%).

This lack of consensus is also reflected in textbooks: Fernández (2008) reviews 100 textbooks on corporate finance and valuation published between 1979 and 2008 and finds that their recommendations regarding the equity premium range from 3\% to 10\%, and that 28 books use different equity premia in various pages.

The average Market Risk Premium (MRP) used in 2008 by 487 professors in the United States (6.3\%) was higher than the one used by 224 of their colleagues in Europe (5.3\%). The average MRP used in 2007 was 1.5\% lower than the one used in 2000. 15\% of the professors decreased their MRP in 2008 (1.5\% on average) and 24\% increased it (2\% on average). 66\% of the professors used a lower MRP in 2007 than in 2000 (22\% used a higher one).

The comments from 180 professors that illustrate the various interpretations of what is the required MRP help to explain the confusion of students and practitioners about its concept and magnitude. Finance textbooks should clarify the MRP by incorporating distinguishing definitions of the four different concepts and conveying a clearer message about their sensible magnitudes.

The lack of consensus about the MRP is an effect of the fact that "The required MRP" and "The Expected MRP" do not exist: different market participants require different MRP and have different expectations.

How does this survey link with the Equity Premium Puzzle? Fernández et al. (2009), argue that the equity premium puzzle may be explained by the fact that most market participants (equity investors, investment banks, analysts, companies...) do not use standard theory (such as a 
standard representative consumer asset pricing model) for determining their Required Equity Premium, but rather, they use historical data and advice from textbooks and finance professors. Consequently, ex-ante equity premia have been high, market prices have been consistently undervalued, and the ex-post risk premia has been also high. Professors use high equity premia (average around 6\%, range from 3 to 10\%) in class and in their textbooks, and investors use higher equity premia for valuing companies (average around 6\%). The overall result is that equity prices have been, on average, undervalued in the last decades and, consequently, the measured ex-post equity premium is also high. As most investors use historical data and textbook prescriptions to estimate the required and the expected equity premium, the undervaluation and the high ex-post risk premium are self fulfilling prophecies. 


\section{Exhibit 1}

Mail sent on January 2009

I am doing a survey about the Market Risk Premium that we, professors, use to calculate the required return to equity.

"I would be very grateful if would kindly reply to the following 3 questions."

Of course, no individuals or schools will be identified and only aggregate data will be made public.

Best regards and thanks,

Pablo Fernández. IESE Business School. Spain

\section{3 questions:}

1. The Market Risk Premium that I used in 2008 was

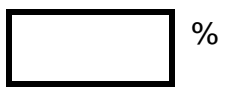

2. I justify this number:

I do not justify the number

Reference to books or articles

Which ones?:

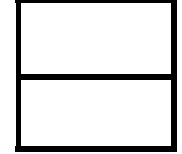

3. In previous years, I used different premia

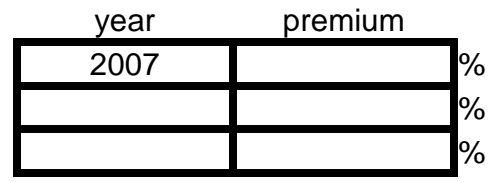

Comments 


\section{Exhibit 2}

Comments of 78 professors that did not provide the 2008 MRP used

1. I am an academic and have no need to calculate a MRP. If I did calculate one, it would have changed at different times during the year.

2. I don't think about these things. I am not a practitioner.

3. I am a theoretician, not a practitioner. Hence $M R P=R_{M}-R_{F}$ finish.

4. I have never used a MRP as I don't think such calculations are very meaningful.

5. I never have specified a MRP in my research.

6. I have not used MRP: I am shifting my focus from research to int. teaching and consulting.

7. Who knows what the premium is if we don't even know what the "market" portfolio contains.

8. I find that the CAPM is not very useful nor is the concept of MRP.

9. While the CAPM is a very elegant model, it is not very useful to the average investor.

10. I am not a believer in CAPM. It does not reflect the way real investors make decisions. I manage two portfolios, each with about 15 to 20 securities. I ran several screens (in 2008) for selecting stocks: PEG $<1.3$; dividend yield $>5 \%$; PER $<10$; price $<\$ 50 \ldots$ Overall, I was in and out of the market at least 3 times in 2008. As 2009 opens I am 85\% invested.

11. It is hard for me to answer such a theoretical question without changing my mind.

12. I use risk premia numbers that are industry and firm specific. In particular, I favor using the firm's ROE and then I compare this with market and industry averages.

13. I do not invest directly so do not use MRPs.

14. I do theoretical corporate research (and generally, my models have risk-neutrality).

15. I find MRP concept so arcane, I don't use it and don't waste time with it. I was an investment banker for a couple years (prior to squandering 5 years on a PhD). Never did we worry about the theories that academics - many of whom, I might add, have never held a real job in their life - spend their entire lives studying. So I don't worry about it. I tell the students to compute their cost of equity based on current market pricing.

16. I believe MRP fluctuates, but it is hard to measure.

17. I have never used a MRP as I don't think such calculations are very meaningful.

18. The MRP varies from one market to another and from one risk averse investor to another.

19. I teach derivatives: I did not have to use a MRP. I have no idea what it is or should be! 
20. I expose students to arguments posed for the use of historical arithmetic average and geometric average and surveys and how estimated premiums change through time. I then emphasize the forward looking nature when using MRPs in applications.

21. Sustainable valuation and speculative valuation are two different kinds of sport, but we often confuse both arts. Distinction should be drawn between valuing businesses as 'enterprise' and as 'speculations' (Keynes, 12th Chapter of "The General Theory"). I would not use stock market based premium as the basis for establishing a sustainable discount rate.

22. I do not usually explicitly use MRP in my consumption or investment decisions.

23. In calculating the required rate of return on equity I regard to the specific security risk calculated by reference to Beta. This method generally results in a MRP of 2-4 times the risk-free rate.

24. I have been teaching Econometrics, Capital Markets, Corporate Finance and Investments to graduate students. I do not specifically provide a number for the MRP.

25. For 2008 should be a negative number or positive and less than the risk free rate. A rational investor would have moved his portfolio from equity to debt instruments in early 2008.

26. It depends on the oil price development but on average I normally use $15 \%$ in November through April and $-5 \%$ in May through October based on the Halloween Indicator Sell in May and go Away study in the AER 2002.

27. In Australia last year the market went through big shocks, experiencing a negative return for most of the benchmarks. Hence, a negative or almost 0 expected return cannot compete against the interest rate, which was around 5\% for the T-bills. Similar situation in 2007.

28. Until about 2001, I used 8-8.5\% the MRP from history. In late 1990s, articles appeared that claimed this premium was high and will be lower. Since then I use a range of 5-8\%.

29. The MRP has certainly been changing over time (see data of Toronto Stock Exchange).

30. My investment process does not hinge on explicit estimates of the MRP.

31. I generally do NOT advocate using a MRP at all - rather, I argue that one should estimate the individual components of the CAPM, which insures consistency. However, given that people do use it my argument for 2008 was for a figure between $2 \%$ and 4.3\%.

32. The MRP is some sort of weighted average of ex ante and ex post returns. However, I think current market conditions should very much lead us to prefer a direct estimate of $E(\mathrm{Rm})$ rather than an expected MRP. The $\mathrm{E}(\mathrm{Rm})$ figure is more stable than the $\mathrm{E}(\mathrm{MRP})$ figure.

33. I don't think about the MRP. I think about premia for particular categories of stocks.

34. I don't teach anything which requires MRP. If I did I would use the market volatility.

35. The historical MRP of almost all countries in the world was negative: between minus 50\% to minus 70\%! The ex post (CAPM-based) MRP was heavily negative. 
36. It has been negative in the United States over the 1,3 and 5 years. What are safe securities now? United States Treasuries! They have the economic (highest living standard, highest productivity), financial (60\% of world transactions denominated in United States dollars), political (Transatlantic and trans-Pacific alliance), military (12 aircraft carriers...) and moral power (democracy above dictatorship and individualism above collectivism) of the United States behind them.

37. In the 1997-1998 Asian Financial crisis I learned that even a well-diversified portfolio manager cannot be insured against this situation when all markets head south simultaneously.

38. Asset value is rationally computed as discounted expected future cash flows. When those expectations are dashed in ALL markets ( $=$ a complete loss of confidence in the financial markets all over the world), ALL asset values collapse.

39. When it became clear that the United States would elect again a socialist as its president (the last one was FDR in the 1930s, who had presided over nine years of depression and then was forced by his enemies to enter WWII!), the confidence of the major global investors in the future growth of the world economy was deflated.

40. I don't use a MRP, but I recommend one to my class for use. Market conditions (up until fourth quarter 2008) indicated a MRP of 1\%-2\%. This could play out as a longterm market return that would be low, or a radical revaluation of the market. I only half believed the latter, but maybe I was right.

41. I look at the embedded market return at the time a decision needs to be made, and then dissected it starting with the risk-free rate and the MRP.

42. I teach that the MRP is not at all constant and it can vary even sharply. So, I am not able to provide you with a percentage which is valid for one whole year. Furthermore, I think that considering an average of all the MRP does not make sense either.

43. I use a variable MRP: the Implied MRP in the market prices.

44. It does not make any sense to use a MRP in 2008. The market is simply out of any possible equilibrium!

45. I just use the MRP that is stated in the problems. Typically, a textbook writer comes up with these estimates - not me. So, the MRP could be any number of things.

46. My main teaching and research area is corporate finance and I don't use MRP frequently.

47. I don't guess at a MRP... My students tend to use 5\% (from their corporate finance classes) as a starting point before sensitivity analysis for the uncertainty about the rate. Do we want to use the 30-year United States bond when yields are under 3\% (and there are reasonable claims that this is the mother of all bubbles)?

48. As a business person I do not use MRPs for either establishing target direct investment returns or portfolio decisions. Business folk use time horizons.

49. I may unconsciously have a MRP, but it must be a figure that changes daily. Conditionally on the daily news, I may have a MRP for the day. I don't know the daily figures. 
50. My strategy to invest doesn't depend on a risk assessment of the market. The MRP is just an academic toy.

51. I do not recall having to use a MRP figure in 2008. It doesn't come up a lot in options.

52. The historical MRP for equity indices of almost all countries in the world was negative: between minus 50\% to minus 70\%!: the ex post (CAPM-based) MRP was heavily negative.

53. I would tend to use whatever MRP is specified in the textbook. I also tend to tell students that estimation of such numbers includes an element of judgement, since we want a forecast of the MRP, not a backward-looking historical estimate.

54. In my experience, MRP differs by market, product/investment type and other variables.

55. I began my academic career a firm believer in Graham and Dodd. I am now less so and leaning toward technical indicators. I still like strong balance sheets, but as the scandals of recent years (especially the current SATYAM scandal in India), "balance sheets are like fine perfume - to be sniffed but not swallowed."

56. In order to estimate the conditional mean on the aggregate equity market, I'd personally fit a VAR(p), potentially with regime-switches in parameters according to a hidden Markov Chain model, and use the optimal predictor from such a system.

57. We advise students to use the average return over a longer time period from a broad market index from the main market, the company operates in. Hence, our used MRP depends on the company we look at.

58. I never use only one number but simulate on a larger scale through the sample definition space and then observe the effects of small perturbations.

59. I do not try to identify a specific MRP. I just discuss the concept.

60. I try to teach critical thinking by my students and in particular ask them to defend their choice through clear, consistent, concise and convincing arguments; I do not give my students a MRP so as not to bias their work.

61. That I used where? In teaching corporate finance? Asset Pricing? In my research? In consulting?

62. I did not have to use an estimate of the MRP in 2008. But if I have to, I may check recent Vernimmen newsletters.

63. I try to make the students justify the number and try to get them to use a premium that reflects the expectations of an appropriate benchmark such as Nasdaq, S\&P 500, small cap, mid-cap, etc.

64. We take cost of capital as given (almost as if it comes down out of the sky!). I guess what we want to get across to the students is the various accounting issues and financial reporting issues that arise whatever cost of capital estimate you use.

65. I calculate MRP quite often but don't remember the specific numbers about MRP.

66. I do not justify the number because it is very difficult to justify. I have been interested in multifactor models for a period and I feel that the use of a simple one factor model based 
on the market model is not a good indicator of the required return for valuation purposes... I feel that finance has a long way to go before we really understand the determinants of the value of an asset and the most appropriate discount rate to use in valuation.

67. Using the MRP in determining expected rates of returns? I think it's a joke.

68. In my classes I usually calculate the MRP by using as the risk free rate the current market rate on T-bills for the money market and the rate on the 10 Treasury for the capital market.

69. The SEP500 Index yielded about a negative 33\% rate of return for 2008. Long-run average data should be used, not current data.

70. The MRP varies during the course of a year. At any moment, I believe it is appropriate to use the AAA 10 year bond rate $+1 \%$ (in very good periods) - $+5 \%$ (in very volatile period).

71. Having no funds to invest, I did not bother about any MRP.

72. I never have used or estimated the MRP. If I were to do this, I would merely look at the difference between the standard deviations of the average prices in the overall stock versus the bond markets over a year.

73. In Brazil, we have 3 problems for estimating MRP: i) lack of long term data; ii) sharp past stock market volatility; and iii) absence of a correct and stable risk free rate. Virtually all valuations in Brazil are carried out by estimating the cost of capital of a similar company in the United States (10-years T-Bond rate: 4.5-5.0\%; Ibbotson MRP: 6-7.0\%), then adding the risk-country premium (1.5-2.0\%); and the difference on the expected inflation of the two countries $(4.0 \%-2.5 \%=1.5 \%)$.

74. Over the last 10 years the stock (equity) market in Russia scored in excess of 12-13\% over safe bonds. This is the observable MRP measure I would report to you.

75. In 1983 the Soviet Academy of Sciences recommended using a uniform discount rate of 15\% for assessing investment projects. In 1960-1980 the thinking was that each industry is to be characterized by a sui generis discount rate varying from less than 10\% to 33\%.

76. Here in India I generally assume that Indian stock market is expected to give $24 \%$ annual return. Taking into account this return expectation I estimate the required rate of return.

77. India. The expectation of market risk for a year is unrealistic because of the dynamics of the market force. But we cannot ignore it. What we can do is that by considering the yearly risk a tolerance limit can be determined to see how much risk we can bear or withstand for investment decision.

78. In the absence of a risk-free gov. bonds market in the United Arab Emirates, it is hard to calculate MRP. Recently "national bonds" have been offered by a private company, 50\% owned by the government of Dubai. I wonder if we can consider them as "risk free." 


\section{Exhibit 3}

Comments of 104 professors that did provide the 2008 MRP used

1. $5 \%-6 \%$ in United States. As the MRP is a long term assessment it cannot change every year based on the volatility of our sentiment which is what the market captures most of the time. What changes is the risk free rate which is a reflection of economic conditions looking ahead.

2. We work problems with one MRP but not always the same number.

3. Australia: I used a MRP of 7-8\% with reference to word of mouth quotes from practitioners. Practitioners have led me to quote: "double the risk-free rate."

4. I recognise the importance of the MRP, but I know how difficult it has been to get a good estimate of what this prospective value is/should be. I simplify the exposition for students; but I do emphasize how noisy the estimate is.

5. I usually give the same premium 5\% each year as I think this is a reasonable number a priori. I have read quite a lot on the MRP and the different ways it can be derived and the conclusions that are derived from these approaches and fully recognize the huge possible range in the MRP (1\%-9\%)! So my 5\% is a gut feel prosaic choice.

6. The MRP that I used (United States) in 2008 was $-39.96 \%$. I justify this number with Kenneth French's website. In previous years, I used different premia: 2.63\% in 2007, $11.4 \%$ in 2006 and 4.35\% in 2005.

7. The MRP I used (3\% Europe) is historically low compared to the range predominant in the literature (4-6). In my opinion this reflects the sharp decrease in risk aversion observed from 2003 to 2007.

8. I look at MRP as the volatility in the market. If the volatility is high as it is right now, I want more premium for investment.

9. $10 \%$ United States. I justify it, but it changes during the year. I use expected market performance minus 10 year treasury. For 2008, it was about an expected market of $14-18 \%$ and T-bill of about $6 \%$. Thus, $10 \%$ worked... but that is too high for the long run.

10. $8 \%$ United Kingdom. I think more in terms of risk attitude which evolves only slowly. Local risk aversion (Arrow-Pratt) may have move from less than 4\% to 6\% or more over the last year.

11. United States. I emphasize that there is substantial uncertainty regarding the MRP and that it is likely varying over time. I use long-term historical averages, but explain that the correct value might be anywhere between 5\% and 10\%.

12. $4.60 \%$ United States. I have used the same premium over the past few years.

13. Australia. My perception is that generally, the MRP is lower than what most people believe. Hence, the downward trend in my (subjective) estimates.

14. $13.5 \%$ United States. Ibbotson (+ adjustment for market turmoil and my lowered net worth). 
15. Finland. Main inv. banks and consultants apply either 4 or $4.5 \%$ and it makes sense (e.g. in M\&A) to use what others are using. Mckinsey has a study supporting premium of this size. When teaching I also show international historical evidence which suggests $5.5 \%$.

16. United States. In today's market, the applicability of a 5\% (versus something much higher to offset the abnormally low Treasuries) is dependent on separating the aggressive monetary resuscitation attempts by the Fed from the actual riskless rate - this difference is evident in our new term structure, as well as observation of Treasury futures.

17. United States. 4.82\%, 4.94\% and 4.80\% in 2008, 07 and 06. We spend A LOT of time walking through historical MRP over T-bills and T-bonds using both, geometric and arithmetic average. The historical geometric MRP over T-bonds is the starting point for the above numbers. We then consider the current Implied MRP from a Gordon or DDM type of model using analyst estimates (Damodaran Data). Our students then are encouraged to justify their own MRP in their DCF models.

18. United States. 5\%. Historical MRP for large United States stocks lie in range of 5\% to 8\%. I use my personal judgment to estimate MRP but strongly believe it lies within this historic range (5\% to $8 \%$ ).

19. For 2007, I used a MRP $=9 \%$. For $2008=12 \%$. For $2009=15 \%$. With the Risk Free Rate so low, virtually zero, all the "risk" is "market risk". Obviously, the "market" is very volatile. When you add specific company risk (measured by Beta) to the equation, the Required Rate of Return is composed of only "market risk" and "company risk". I think that justified a pretty high MRP. Obviously, this assumption will really limit your investment alternatives. I base these numbers (12\% \& 15\%) on my own intuition and articles I've read in Business Week Magazine.

20. Netherland. I'm teaching master classes, so I emphasize that we do not really know this number with certainty (I give a range of 3-5\% as a rough figure), and stress that the required return to equity as well as the risk-free rate depend on the state of the economy.

21. Japan. 2008, 6.82\%; 2007, 6.60\%; 2006, 6.74\%. Statistics used are earnings yield, dividend yield (corporations' own estimates for next 1 year accounting period) and price-to-book ratio. Based on those numbers, market-implied MRP is calculated by using T-model that captures "forward looking supply-side" ERP.

22. The Expert Committee on Cost of Capital normally work with a range of parameters to start with to arrive at a range of cost of capital before picking a point estimate.

23. $9 \%$ United States. I learned the MRP to be about 8\%. And this number seems valid still to me. I suggested $9 \%$ for 2008 to account for the higher volatility in that year. According to $1900-2000$ data, the mean was $8.7 \%$.

24. United States: I mention the historic work that's been done. I think it's important to discuss that there is a premium and that it can change. But you have to use some number, and $7 \%$ is as good as any, especially these days! 
25. I use the historical United States Sharpe ratio of 0.1 and the sample standard deviation of United States excess return in 2008 (2.6\% per day in 2008). Then the MRP $=0.1 \mathrm{x}$ 2.6\% per day. 2007: $0.1 \times 0.1 \%$ per day.

26. United States. The MRP that I used in 2008 was 8.5\%, the 1926-2005 MRP to large company stocks. I stress that there are different ways to measure this and this is only an estimate.

27. United States. 2008: 5.7\%. I explain that this value is subjective. I emphasize that different researchers/firms use different values. However, for our class, it is helpful that we all use the same value, so we use this one. It comes from a study that a colleague did about Historical MRP from 1900 to 2000 using 10-year rolling averages.

28. Denmark. 4.5\% for the Danish market. There are discussions going on among practitioners whether the MRP has gone up in the second half of 2008 (due to the financial crisis).

29. Netherland: I see this figure as a long-term value, and short term price variations should not affect it. I find it hard to explain that a company can be worth a lot more or less than the year before because of stock-market movements.

30. Germany. It is more important to conceptually understand MRP than to calculate it precisely.

31. United States. 4\%, slightly below historical long-term MRP, as reported in Dimson et al. I don't generally change this number.

32. United States. The MRP that I used in 2008 was 5.51\% (geometric United States stock vs. t-bond average premium 1928-2000). When using 1-year models in a different course, I have also used the arithmetic average (8.4\%) premium (stocks vs. t-bills 1928-2000).

33. United States. The MRP that I used in 2008 was 6.5\%. I always explain that the range can be from $4 \%$ to $10 \%$, but in recent years many Wall Street analysts use $4 \%$ to $6 \%$.

34. United States. I D0 justify the number I use (4\%) by indicating this is a belief held by Buffett and many prominent academics.

35. Germany. I used $1 \%$ in 2008. $1 \%$ in 2007, 10\% in 2006 and 2005. MRP in a conditional model is time-varying, and basically to simplify the issue I would use only 2 regimes with constant MRP for each of them - good regime with MRP of 10-12\% and bad with expected MRP of about 0\% (bit higher to avoid problems with rational investors shorting the market).

36. United States. I do estimate it using a 50-year historical average.

37. United States. MRP changes with market conditions, based on risk aversion and market volatility, and that $4 \%$ is only for example purposes. I am thinking of rewording my problems so as to vary the MRP, with a phrase like... current market conditions suggest a _ $\%$ MRP.

38. United States. The exact value of the expected MRP is not a well-agreed. However, the magnitude around $6 \%$ is more accepted. 
39. China. 2008: 5\% for developed markets; 7\% for China/HK.

40. United States. I usually justify a $6 \%$ by suggesting that historical MRP given in textbooks (around 8\% or higher) might not be relevant. There is great deal of research to suggest that MRP has declined reflecting changes in risk preferences of diversified investors. I have used historical MRP ( $8 \%$ or higher) given in Brealey et al. and other textbooks in the past.

41. Denmark. I justify my $4 \%$ by a combination of: 1) historical MRP, and 2) economic reasoning where I find it difficult to justify such high MRP.

42. United States. 12\%. In 2008 investors demanded 10\% for debt and preferred stock, or $8 \%$ above risk free; therefore, the MRP must be higher.

43. France. I have used 5\% the last 10 years. I do not really justify it but I do show to the students LBS study showing 5\% difference between real returns of equity and bonds. But I do emphasize that the future premium can easily be something else. Until the crisis I said that it is probably lower now than in history due to diversification benefits.

44. United Kingdom. MRP $=5 \%$ (Ivo Welch 2008 survey). My view for some time has been that the equity premium is low, probably around 3\%. For teaching purposes, I use a higher number to reflect broader academic opinion.

45. United States 6\%. I do not justify the number. I always run scenarios with different MRP. Also, I have been using 6\% for a while now.

46. United States. The Historical MRP has been 7\%. HOWEVER, I tell the students that any number $1 \%$ or higher is justifiable. $7 \%$ is the right number in normal times. Late 2008 was not normal: A-rated bonds were yielding $8 \%$, which was about $600 \mathrm{bp}$ above the riskless interest rate. The stock market should be priced to yield more than the yield spread on A-rated bonds. In the last quarter of 2008, the MRP I used was 10\%.

47. United States. 7.5\% (1929-1999 Historical MRP). Depending on the market circumstances I have occasionally made ad-hoc (gut feeling) changes (never been greater than + or- $1 \%$ ) to this rate. I have heard many valid arguments that the rate should be as low as $5 \%$, however the resulting valuations from using such a rate are often unjustifiable.

48. United Kingdom. I don't justify the premium: one can find research that shows it anywhere between 3\% and 9\%. I tell students that I use 5\% because even at the peak of the 'Goldilocks economy' I felt uncomfortable dropping below that. I haven't yet increased above $5 \%$ because as yet, none of my corporate clients has increased its cost of equity.

49. There was a view that markets were getting more efficient and risk was being better managed in the early 2000s, which led analysts and myself to consider trimming MRP, however as increasing financial leverage and expansion of derivative products took off, the prospect of increased volatility was overlooked by many.

50. United States 16.4\%. I used the small cap stock risk premium (1926-2006). 
51. United States. I use many different market risk premia in each individual class because I want to emphasize to the students that the MRP as defined by the CAPM is time varying. The range I have used as examples is generally between $5 \%$ and $12 \%$.

52. United States. Relative to t-bill rates, I've used 6-6.5\% for many years. But that's based on historical returns. The CAPM is pretty useless right now - many students end up with a cost of equity that is less than the company's cost of debt.

53. United States. I always use the same definition of MRP: historical MRP vs. T-bill rate (either 3 month or 1 year). I use it because most textbooks and journal articles define MRP this way.

54. The questions clearly presume use of the Sharpe-Lintner-Mossin version of the CAPM.

55. United States. I tell students that estimates today are typically between $2.5-4.5 \%$ and that one reason to think that the expected equity premium has decreased is because of increased stock market participation.

56. United States. I do not justify the 6\%. It feels good. As a friend used to say, "if it feels good do (use) it." Educated guess. We can't estimate it properly with such limited data. Everyone seems to have forgotten about Roll's critique.

57. United States. 5.7\% not justified. I explain that this value is extremely subjective and that there are a variety of methods to come up with a value. I emphasize that in practice, different researchers/firms use different values. However, for our class, it is helpful that we all use the same value, so we use this one. It comes from the historical MRP of the S\&P 500 vs. the 10-year T-note from 1900 to 2000 using 10-year rolling averages.

58. United States. 4\% from Ibbotson \& Chen (2003). Previously, I used historical ERP from 1926 on as reported in Ibbotson associates. I used to use historical, but have switched to the supply side method mentioned in the Ibbotson \& Chen article above.

59. United States. 2008: 5.5\%. 2000: 8\%. I have updated based on better information and interpretation of long-term historical data across countries.

60. United States. MRP continues to go down as new data are incorporated for its estimation. It really makes no sense to use one ballpark number for MRP as market condition changes.

61. United States: I was wedded to the geometric mean (SBBI) but have been moving toward the SBBI arithmetic mean with adjustments.

62. United States. Over past years, 4-7\% based on historical and prospective analysis. However, this semester I am using only a 7\% MRP and in addition using a premium over corporate bond yield as an alternative to CAPM. Specifically, I am using a 3-4\% premium over the firm's corporate bond yield because I have encountered cases where even using a 7\% MRP over 10 year Treasuries results in a cost of equity below the firm's bond yield- an unreasonable answer since equities are riskier than bonds. 
63. France. 4.5\%: if we are looking for a company intrinsic value, we should use long term averages. This approach is the one recommended by the Valuation Experts association in Lyon. But in an IPO (just dream!) we should use the present future oriented MRP (presently more tan 10\% in France, according to Associés en Finance).

64. France. We should use a long term average. Do not forget CAPM is essentially a conceptual framework, with little empirical validity. Using common sense to fill in the numbers is a way to warn against the dangers of putting too much scientific value on the outcome.

65. United Kingdom. 2008: 9\% Several risk factors were high by historical standards (volatility, although mostly idiosyncratic, liquidity, and systemic - high co-movements internationally and across asset classes). This pushes my required MRP (which in fact does also summarize all these other omitted factors) well above historical average (unconditional mean, which I would place around 4\% per annum). 2007: 5\%.

66. United States. The MRP was actually negative in 2008 because market returns were less than RF.

67. United States. In class I use 4-6\%. I justify it by citing academic research, even though I feel that number is wrong. If I use $9-10 \%$ for a MRP estimate as a result of my own research, it would be very complicated to explain to a class of students. It's just easier to repeat what is generally thought to be the "best guess."

68. Australia. 6\% approximates the long-term historical MRP vs. long-term government bonds yields in the United States and Australia. But I am yet to observe any reasonable model for computing a cost of equity capital at a specific point in time. Our tools are really only useful for generating estimates over a period of time, not at one particular point in time.

69. United States. Since there is such a wide disparity among what the "correct" MRP should be, we choose to use $5 \%$ as being about in the middle of all estimates. We ask each student to use the same number, 5\%, so that their valuations are "apples to apples."

70. United States. I used the value-weighted market return of NYSE, AMEX, and Nasdaq $\mathrm{T}$ bill rate for monthly MRP.

71. Norway. 4\%. Historical equity returns are exaggerated due to one-off improvements in institutional quality strengthening shareholder power and (permanent) lowering of capital taxes.

72. United States. 7\%. I am interested in whether the use of market data beginning immediately after the crash of 1929 inappropriately skews (raises) the MRP.

73. Germany. My gut feeling tells me that a range of 4-5\% with a declining trend would somehow reflect the average I have used for central European targets in the last 3 years. 
74. United States. In 2008, I held no stocks at all. I thought the market was requiring too low a return, lower than zero. I justify it by the fact that I was correct. I abandoned stocks in 2007 and even before that. But especially in 2007, it became clear that the return was going negative. Rozeff work says that dividend yields are MRP. In that case, the MRP was less than 3\%.

75. Switzerland. In 2008 6-8\%. In the early nineties, I used 8-8.5\%. Then, along with the boom, I progressively went down to 6\% (never below). After the 2000 bursting of the bubble, I learned my lesson, and I have been telling students since that the premium is between 6 and 8\%, below 6\% too small and above 8-9\% too large.

76. United States. 6\%. I do not justify it because MRP is ex ante.

77. My 4.5\% MRP comes from financial economists that realistically doubt the future ability of the United States to achieve premiums greater than the rest of the world. Warren Buffet and others also espouse similar expected levels.

78. I use Welch's survey. [yes, I am aware of the paradox that if academics cite their own collective opinion it is hopelessly self-referential]. For other countries, I teach adding country risk premium following Damodaran.

79. United States. I rationalize the $6 \%$ with data \& stories.

80. United Kingdom. I usually calculate premia in shorter intervals and or adjust the longrun premium up or down in accordance with the most recent premium calculated in a shorter interval.

81. Israel. I was not able to say ex-ante in any of the preceding recent years that the market was "riskier than usual."

82. France: $6 \% ; 3.5 \% ; 3 \%$ (2008, 7 and 6$)$. These changes are motivated by the sustainable growth for most sectors of industry.

83. United States. 2008: 4-8\%. 2007: 8.28\%; 2006: 8.37\%; 2005: 8.34\% = United States MRP 1926-2005. Like betas, they keep changing. It takes hundreds of years to accurately estimate the expected return on the market using historical data.

84. Canada. For 2009 I might use a higher MRP. The MRP is over long term bond yields; nobody in practice uses a MRP over T Bills except academics.

85. France. The MRP is as volatile as the market. There are other sources of measures for risk aversion such as credit spreads. When asked for an order of magnitude, I tend to mention between 4 to $8 \%$ for the market index risk, as a personal synthesis of various documents or books that I have been exposed to.

86. France. The MRP that I used in 2008: NATIXIS Securities (Journal des Finances): 25/09/2008: 5.35\%; 02/10/2008: 5.80\%; 16/10/2008: 6.97 \%; 23/10/2008: 7.09 \%.

87. United States. My preferred method is the "Shiller PE ratio" of the S\&P 500 divided by a ten-year moving average of inflation-adjusted earnings of the S\&P 500 (available on Robert Shiller's web site) as the expected geometric real return on stocks, minus the yield-to-maturity on 30-year inflation-indexed bonds (TIPS).

88. China: The subprime loan crisis makes me increase the required MRP from $8 \%$ to $10 \%$. 
89. In South Africa we have several anomalies. For example blue-chip companies can borrow at rates of 1\% or more below the lowest government T-bill or bond rate, so what is a "risk-free" rate? Secondly the market is essentially split in two with our top 40 shares having a substantial international investor base while share below those have almost no international investors. Accordingly, we should have two sets of expected returns and market risk premia!

90. $4 \%$ for the Swiss market and Europe, 3\% for the United States, 2\% for Japan. I do not justify the number: these figures are my personal guess. I do not focus on historical averages of excess returns (these figures are too high). Rather I prefer residual income based (RIM) estimations of the MRP. While Claus and Thomas (2001) get MRP of around 3\% for various markets, I would expect that the equity premium is somewhat higher in Europe because of the low stock market participation rate.

91. Romania. $14.3 \%$ in $2008 ; 20.4 \%$ in 2007 . These are historical estimates of equity premium for the Romanian market (1998-2008). Depending the goal of my research, the methodology can change (in estimating the required return on individual stocks, for example, I consider a more recent period to be more appropriate when computing MRP).

92. United States. I have been using 4\% as a long-run MRP for quite a few years now. As mentioned above, I place weight on both observed returns as well as the implied premium given year-end prices on the S\&P 500. In my courses, I strictly use a longrun premium so I have not had much need to change it over time.

93. Spain. For academic people, these questions are hard to answer because the academic studies use the history to estimate this value. Of course, one can use some models to predict this value for many years. However, there is a huge literature about predicting the MRP with different conclusions. I expect that professional people (investors) have more information and can answer these questions with more precision since, for sure; they need to know this value to make their decision.

94. United States. There is no consensus as to whether a historical or expected rate should be used.

95. Middle East. 7.5\% applies to the United States market. However, if I am valuing a company now in United States I would definitely use a higher MRP, maybe 9\% or 9.5\%. In the Middle East I would increase the MRP from 6.5\% last year to about 9\% or $10 \%$ this year.

96. United States. I calculate it each day from the The Wall Street Journal.

97. MRP increases as $\mathrm{P} / \mathrm{E}$ increases.

98. I looked at some studies and decided that 6\% was preferable to the $8 \%$ quoted in many textbooks. Obviously, any historical estimate will depend on the time period used and assumes the risk profile for that period is similar to the risk profile looking forward.

99. Own calculation. GDP growth + inflation $+2 \%$ for equity risk. 
100. United States. 1\% in 2005-2008. There has been much research on MRP: Fama \& French, Jaganathan... all suggest the MRP is very low today - about 1\%. I also listen to Warren Buffett who suggests that stocks will return about 7.5\% over the foreseeable future. Risk free bonds are about 5\% so this implies a MRP of about 2.5\%. I am a conservative investor.

101. The Market was bad so $4 \%$ is justified.

102. India. $10 \%$ based on the $8.5-12.5 \%$ band estimated by professors Varma and Barua at the Indian Institute of Management at Ahmedabad.

103. Israel. 7.5\%. This is the assessment of what an average investor wishes to receive as an incentive to move eu1 from an investment in a perfectly safe investment (risk-free) to a well diversified mainly stock portfolio, and we have no theoretical basis to establish what this number is. So the answer is based on 'gut feeling' more than anything else. Students must realize that there's no direct observation nor any theoretical basis to establish or empirically estimate the EXPECTED return on the market portfolio nor of the MRP.

104. In South Africa (SA), the government introduced tight regulations for money lending by financial institutions including the total loan repayments versus total disposable income for individuals before subprime crisis swept across the world. Therefore, the adverse repercussions of financial markets in SA were not bad as like most countries. Furthermore, it makes sense that the MRP to be fairly stable over the last 7 years in SA. 


\section{References}

Brealey, R. A., S .C. Myers, and F. Allen (2005), "Principles of Corporate Finance," $8^{\text {th }}$ edition, McGraw-Hill/Irwin.

Claus, J. J. and J. K. Thomas (2001), "Equity Premia as Low as Three Percent? Evidence from Analysts' Earnings Forecasts for Domestic and International Stock Markets," Journal of Finance, 55, (5), pp. 1629-1666.

Damodaran, A. (2008), "Equity Risk Premiums (ERP): Determinants, Estimation and Implications,” Working Paper.

Dimson, E., P. Marsh, and M. Staunton (2007), "The Worldwide Equity Premium: A Smaller Puzzle," in Handbook of investments: Equity risk premium, R. Mehra, Elsevier.

Fernández, P. (2007), "Equity Premium: Historical, Expected, Required and Implied," http://ssrn.com/abstract $=933070$

Fernández, P. (2008), “The Equity Premium in 100 Textbooks,” http://ssrn.com/abstract $=1148373$

Fernández, P., J. Aguirremalloa, and H. Liechtenstein (2009), “The Equity Premium Puzzle: High Required Premium, Undervaluation and Self Fulfilling Prophecy," IESE Business School WP. http://ssrn.com/abstract=1274816

Graham, J. R. and C. R. Harvey (2007), "The Equity Risk Premium in January 2007: Evidence from the Global CFO Outlook Survey," Icfai Journal of Financial Risk Management, Vol. IV, No. 2, pp. 46-61.

Harris, R. S. and F. C. Marston (2001), "The Market Risk Premium: Expectational Estimates Using Analysts' Forecasts,” Journal of Applied Finance, Vol. 11.

Ilmanen, A. (2003), "Expected returns on stocks and bonds," Journal of Portfolio Management, 29, pp. 7-27.

Johnson, D. T., T. Kochanek, and J. Alexander (2007), "The Equity Premium Puzzle: A New Look," Journal of the Academy of Finance, Vol. 5, No. 1, pp. 61-71.

0'Neill, J., D. Wilson, and R. Masih (2002), “The Equity Risk Premium from an Economics Perspective,” Goldman Sachs, Global Economics Paper No. 84.

Ritter, J. R. and R. Warr (2002), "The Decline of Inflation and the Bull Market of 1982 to 1999," Journal of Financial and Quantitative Analysis, Vol. 37, No. 1, pp. 29-61.

Welch, I. (2000), "Views of Financial Economists on the Equity Premium and on Professional Controversies," Journal of Business, Vol. 73, No. 4, pp. 501-537.

Welch, I. (2001), “The Equity Premium Consensus Forecast Revisited," Cowles Foundation Discussion Paper No. 1325.

Welch, I. (2007), “A Different Way to Estimate the Equity Premium (for CAPM and One-Factor Model Use Only)," SSRN n. 1077876. 